\title{
The Effect of State Ownership and Independent Board of Commissioners Toward Dividend Policy Moderating with Political Connections
}

\author{
Yolanda Hartati Sianturi ${ }^{1}$ and Wiwiek Dianawati ${ }^{2}$ \\ 1,2 Department of Accounting Airlangga University Surabaya, Indonesia
}

\begin{abstract}
The purpose of this research is to find the effect of state ownership and the Independent Board of Commissioner towards dividend policy. Also this research is to find whether the political connections could moderate the relationship among the effect of state ownership and Independence Board of Commisisoner towards dividend policy in company. The population is the whole SOEs listed on Indonesia Stock Exchange (IDX) during 2014-2017 period. This research used multiple linear regression and moderated regression analysis (MRA). The results show that state ownership and Independent Board of Commissioners have no significant effect on dividend policy. After moderated by political connections, it strengthening the positive effect of state ownership on dividend policy, otherwise the effect of moderation does not occur on the Board of Independent Commissioners towards the dividend policy of SOEs.
\end{abstract}

Keywords: state ownership, Independent Board of Commissioners, political connections, dividend policy, Agency Theory, State-Owned Enterprises.

\section{Introduction}

\subsection{Background}

The President election held in 2014 generates new leadership in Indonesia as well as giving the new program for the next five years. Joko Widodo programs that campaigned as called Nawa Cita which means nine priority agendas where one of its points is to emphasized the effort to realize economic independence through strategic domestic economic sectors.

One of the non-tax state revenues are expected to be the government's choice as an alternative to covering the shortfall of tax revenues is derived from share profit of state-owned enterprises (SOEs) or also known as dividends. The revenue target earned from the company's dividend payout is called Dividend Payout Ratio (DPR). The magnitude of the DPR is stipulated by the government together with the company in line with the company's ability to achieve profit targets.

In the determination of state, it still faced imbalances linked to corporate interests versus government as majority shareholder. Ministry of finance as a party have an interest in increasing state revenues, encouraging SOEs to can generate profits according to state revenue targets at the beginning of the fiscal year. From the other side, SOEs target is tailored to the needs of the company in corporate project planning forward. The dividend then becomes the thing which is transactional between the interests of the government and SOEs then decided at the General Meeting of Shareholders (GMS).

Dividends will be used to meet the needs of the state budget when tax revenues have not reached the budget target. SOEs are becoming less competitive with private ownership companies because they share less cash dividends and prefer to distribute share dividends. (Gang Wei, Zhang, \& ZeZhong Xiao, 2004). The company's ownership structure with at least 51 percent of state ownership implies that it still large influence from the government in the selection of company policy. Agency conflicts in these concentrated leadership structures are the practice of expropriation towards the minority shareholders. In this practice the controlling shareholder has 
the possibility to transfer funds from one company to another in order to benefit the controlling shareholder (Friedman, Johnson, \& Mitton, 2003).

One feature of governance that gets the most attention from this research is the independence of the directors, or in other words, the percentage of directors who are thought to be external, or unrelated to the internal manager (executive) and the effect on reducing agency costs between agents (executive managers) and shareholders (Fama, 1980; Hermalin \& Weisbach, 2003). The Board of Directors is used to represent the Board of Directors and Board of Commissioners in countries such as the United States, Canada and the United Kingdom. These countries use a single board system for the structure of the Board of Directors. While in Asia, such as Japan, Korea and Indonesia, the Board of Directors is equivalent to the Board of Commissioners, because it embraces dual board system as governed by corporate governance rules in Indonesia.

The influence of government in the company's policy, especially on state-owned companies, indicates that there are a political relationship between the government and the company. This political relationship leads to agency costs. Governments tend to intervene the policy of politically connected companies ( $\mathrm{Li}$, Song, \& Wu, 2015). Political connections to state-owned companies incur costs. Governments tend to do more intervention in companies that have political connections ( $\mathrm{Li}$ et al ., 2015) by hiring unqualified personnel to fill strategic positions in state-owned companies .

When a CEO has a political connection with the government, the characteristics of corporate governance and professionalism are become weak (Fan, Wong, \& Zhang, 2007). This then worsened the quality of the company's business projection if the need for professionalism is no longer become a consideration through the members selection of the Board of Commissioners. This further affects the company's revenue decline in the future.

Research questions are:

1. Does state ownership affect the dividend policy?

2. Do the proportion of independent board of commissioners affect the dividend policy?

3. Do political connections weaken the relationship between state ownership and dividend policy?

4. Does the political connection weaken the relationship between independent board of commissioners and dividend policy?.

\section{Literature Review}

\subsection{Theory Agency (Agency Theory)}

Research of Jensen and Meckling (1976), The Agency Theory put forward the agency relationship that underlies the birth of the theory. According to contractual theory, the firm is the connection between the various contracts (nexus of contract). The company is said to be a collection of contracts between the owner of the economic resources (principal) and the manager (agent) as the party responsible for the management of the resources (Coase, 1937).

Another issue concerns the occurrence of a conflict of interest in which the management policy is not always in line with the interests of shareholders. This is called the agency type I, the problem between the principalagent (P-A) which then raises the agency cost .

As a majority shareholder, the government has the power to influence corporate policy. Higher dividend is associated with the effective control of the firm which is then deemed able to reduce the agency conflict between the manager and the shareholder, especially if the company has large agency costs (John, Knyazeva, \& Knyazeva, 2011). Ownership concentration through Agency Theory causing shareholders in control management and participate in management decisions causing an asymmetry information for the other shareholders (minority shareholders). This leads to a type II agency conflict between the principals (P-P). 


\subsection{Dividend Policy}

Two alternatives in treating the company's earnings after tax (EAT) are by distributing them to shareholders of the company as dividends or reinvested as retained earnings that management will use to develop the company. In general, the board of directors makes the decision to distribute EAT as a dividend and also set aside to be reinvested. In this case, the Board of Directors must make the right decision in determining the percentage of EAT to be distributed as dividends, hereinafter referred to as the dividend payout ratio (DPR).

Agency Theory states that agency problems can be overcome by conducting several monitoring mechanisms, one of it is to increase the dividend payout ratio. Dividend payouts indicate good corporate management and can be a positive signal for shareholders to reinvest in the company.

The dividends of the state-owned companies is generally distributed by cash dividend. Companies with a high proportion of state ownership pay a larger cash dividends than the individual ownership which prefer paid in stock dividends. (Gang Wei et al ., 2004).

\subsection{State Ownership}

A company with state ownership is a company in which there is a central government shareholding in it hereinafter referred to as a State-Owned Enterprise (SOEs). The definition of SOEs according to Law No.19 of 2003 mentoned that State-Owned Enterprises is a business entity which is wholly or partly owned by the state through direct participation derived from separated State property. State Equity Participation means the separation of state assets from the State Budget or the establishment of a reserve of a company or other source to be used as a capital of a SOEs and/or other Limited Liability Company (Persero), and managed in a corporate manner.

Gang Wei et al . (2004) attempted to investigate the effect of the company's ownership structure on dividend payments by observing 3,994 listed companies in China from 1995-2001. This study states that companies with greater state ownership has a positive and significant relationship to the level of the dividend payment in cash.

High state ownership shows the government has a large percentage of shares. High ownership means the government has a great degree of control over the company. Yu (2013) states that a large degree of state ownership has an advantage because the state provides greater resources and authority. These resources and authorities will help SOEs to increase revenue and ultimately impact on increasing profits.

\subsection{Independent Board of Commissioners}

The Financial Services Authority (OJK) Regulation No. 33 of 2014 states that an independent commissioner is a member of the board of commissioners who is from outside the issuer or public company and has qualified as an independent commissioner. The requirement to become a member of Board of Commissioners shall be regulated through this regulation.

There are at least two members of the Board of Commissioners and one of them is an Independent Commissioner. If the number of members is more than two persons, then the total number of independent commissioners must be at least 30\% of the total members Board of Commissioners based on OJK Regulation above, regarding the Board of Directors and Board of Commissioners of Issuers or Public Companies.

Sharma's (2011) study examined the relationship between the independence of directors and the tendency to pay dividends in 944 public companies in US in 2006. The results show that the larger representation of independent directors on the board has a positive and significant influence on the propensity to pay dividends. The results of this study re-examine the reasons for implementing corporate governance reforms aimed at protecting shareholders during the period 2006-2010

\subsection{Political Connection}

Habib et al . (2017) defines a company with political affiliation if it has at least one large capital owner (may control at least $10 \%$ of the votes directly or indirectly), or a member of the board, or commissioner is: (a) 
Member of the current or previous Parliament; ) Minister or head of local government, or (c) closely related to a politician or party.

A growing study examines the effect of political connections on firms in many areas, including on corporate dividend policies (Su et al ., 2014). Companies with government ownership are more inefficient than those not owned by the government. Political interests can greatly affect the achievement of company performance (Shleifer \& Vishny, 1994).

Political connections to state-owned companies incur costs. The government tends to do more intervention in companies that have political connections ( $\mathrm{Li}$ et al ., 2015) by hiring unqualified personnel to fill strategic positions in SOEs. The rise of Jokowi-Jusuf Kalla 's successful team is considered to have no background rear and ability but occupying the position of SOEs Board of Commissioners implicitly associated with the existence of politics "repayment". This is voiced by the Federation of United State-Owned Workers Unions where they are seeking a lawsuit against the courts to Rini Soemarno which is the minister of State-Owned Enterprises Ministry to publish the results of several Board of Commissioners' eligible feasibility tests including Sukardi Rinakit as President Commissioner of PT Bank Tabungan Negara (Persero) Tbk, Refly Harun as Commissioner of PT Jasa Marga (Persero) Tbk, Cahaya Dewi Rembulan Sinaga as Commissioner of Bank Mandiri (Kusuma, 2015).

When a CEO has a political connection with the government, the characteristics of corporate governance and professionalism are become weak (Fan, Wong, \& Zhang, 2007). This then worsened the quality of the company's business projection if the need for professionalism is no longer have a consideration through member selection of SOE's Board of Commissioners.

Previous research has examined the direct influence between political connections and dividend policy ( $\mathrm{Su}$ et al., 2014). The use of political connections as an indirect relationship or as the moderating variable on dividend policy has not been studied. This study then tries to contribute to filling the research gap by looking at the effect of political connection variables in moderating relationship between state ownership variables and Independent Board of Commissioners towards dividend policy on SOEs in Indonesia. We use five control variable such as firm size, profitability, investment opportunity, liquidity, and debt to mitigate our research model from bias.

Conceptual Framework

Conceptual framework of this research is shown in figure 1

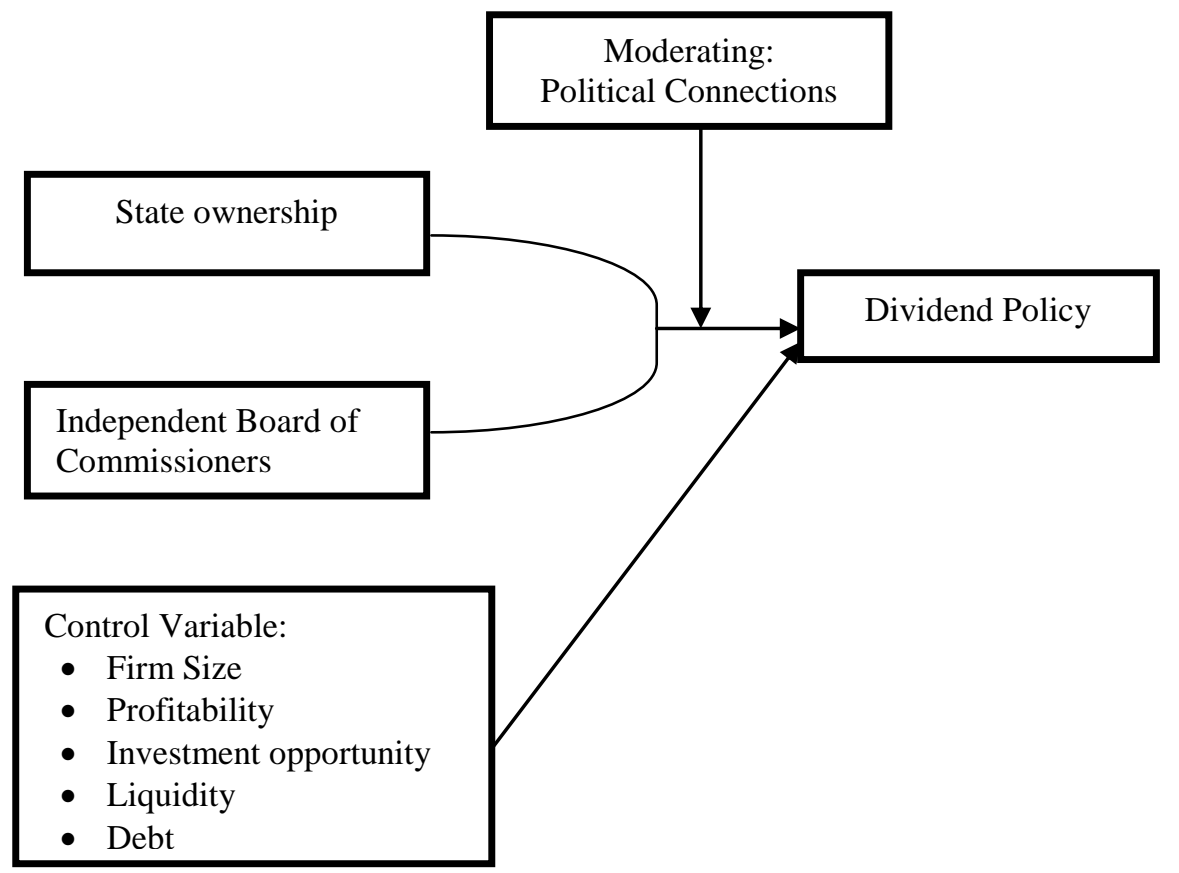

Figure 1. Conceptual framework 
Development of Hypotheses

H 1 : The share of state ownership has a positive effect on dividend policy .

H 2 : Percentage of Independent Board of Commissioners has a positive effect on dividend policy .

H 3 : Political Connections can weaken the influence of state ownership on dividend policy .

$\mathrm{H}$ 4: Political connections can weaken the influence of independent board of commissioners on dividend policy .

Multiple linear regression analysis and moderation regression were used to determine the significance of independent variables such as; state ownership, Independent Board of Commissioners, firm size, profitability, investment opportunity, liquidity, debt toward the dividend policy. The function equation is as follows:

Model I

DPR $\mathrm{t}=\alpha+\mathrm{t}+\beta 2$ INDEPENDEN $\beta$ 1STATE $\beta 3$ SIZE $\mathrm{t}+\mathrm{t}+\mathrm{t}+\beta$ ROAO $\beta 4$ IO $\beta 6$ CASH $\mathrm{t}+\mathrm{t}+\mathrm{t}+\beta$ DEEBT $\varepsilon$

Model II

DPR $=\alpha+\beta$ STATE $\mathrm{t}+\beta 2$ INDEPENDEN $\mathrm{t}+\beta 3$ SIZE $\mathrm{t}+\beta 4 \mathrm{IO} \mathrm{t}+\beta$ ROA $\mathrm{t}+\beta 6$ CASH $\mathrm{t}+\beta$ DDEBT $\mathrm{t}+$ $\beta 8$ POLCON $\mathrm{t}+\beta$ SSTATE $*$ POLCON $\mathrm{t}+\beta 10$ INDEPENDENT $*$ POLCON + DPR

Information:

DPR t

$\beta 1, \beta 2$

STATE t

POLCON t

INDEPENDENT $\mathrm{t}$

SIZE $\mathrm{t}$

IO $t$

ROA t

CASH $t$

DEBT $\mathrm{t}$

STATE $*$ POLCON
$=$ Variable Bound, Dividend Payout Ratio in year $\mathrm{t}$

$=$ Regression coefficient of independent variables in year $\mathrm{t}$

$=$ Percentage of Ownership by Government in year $\mathrm{t}$

$=$ The existence of Political Connection on the Company in year $\mathrm{t}$

$=$ Independent Commissioner of the Company

$=$ Company Size in year $\mathrm{t}$

$=$ Growth Opportunities Company in year $\mathrm{t}$

$=$ Profitability of the Company in year $\mathrm{t}$

$=$ Adequacy of cash owned by the company in year $\mathrm{t}$

$=$ Corporate debt in year $\mathrm{t}$

$=$ Interaction between state ownership and political connections

INDEPENDEN*POLCON = Interaction between independent board of commissioners and political connections.

\section{Research Method}

This research uses quantitative research. Using secondary data obtained through various sources such as journals, internet articles, and books. Data downloaded through the Indonesia Stock Exchange (IDX) website www.idx.co.id in the form of annual reports and ICMD (Indonesia Capital Market Directory) with a population of whole state-owned companies listed on IDX period 2014-2017. This study uses SPSS 20 as an instrument used in data processing.

\section{Research Result}

The result for the first and second hypothesis show with the regression model 1 which is show that the effect of state ownership and Independent Board of Commissioners have no significant influence on the dividend policy. It shows with the result of $t$ test in table 1.

Table I: Output SPSS for $\mathrm{t}$ test for model 1 regression coefficients ${ }^{\mathrm{a}}$

\begin{tabular}{|c|c|c|c|c|c|}
\hline \multirow{2}{*}{ Model } & \multicolumn{2}{|c|}{ Unstandardized Coefficients } & \multirow{2}{*}{$\begin{array}{c}\text { Standardized } \\
\text { Coefficients } \\
\text { Beta } \\
\end{array}$} & \multirow{2}{*}{$\mathrm{t}$} & \multirow{2}{*}{ Sig. } \\
\hline & B & Std. Error & & & \\
\hline (Constant) & $-1,342$ & .318 & & -4.219 & .000 \\
\hline STATE & .022 & .129 & .018 & .171 & .865 \\
\hline INDEPENDEN & -.100 & .112 & -.090 & -.898 & .373 \\
\hline SIZE & .034 & .012 & .492 & 2.902 & .005 \\
\hline ROA & .942 & 285 & .423 & 3.307 & .002 \\
\hline IO & -.075 & .050 & -.145 & -1.504 & .138 \\
\hline CASH & .052 & .031 & .241 & 1.660 & .103 \\
\hline DEBT & -.179 & .087 & -.306 & -2.064 & .044 \\
\hline
\end{tabular}

a. Dependent variabel: DPR 
The equation regression for first regression model is as follows:

DPR $=-1,342+0,022$ STATE $-0,100$ INDEPENDEN + 0,034 SIZE +0,942 ROA -0,075 IO + 0,052 CASH $-0,179$ DEBT

It can be seen from table 1 that the significance of $t$ test for the STATE is 0.865 , greater than 0.05 so it can be said that partially the state ownership does not have any significant effect on the dividend policy. While the $t$ test for INDEPENDEN is 0.373 or greater than 0.05 so it can be concluded that Independent Board of Commissioners partially do not have any significant effect on the dividend policy. Both $\mathrm{H} 1$ and $\mathrm{H} 2$ is declined.

The result of regression model 2 shows in table 2.

Table II: Output SPSS for $\mathrm{t}$ test for model 2 moderated regression coefficients ${ }^{\mathrm{a}}$

\begin{tabular}{|c|c|c|c|c|c|}
\hline \multirow{2}{*}{ Model } & \multicolumn{2}{|c|}{$\begin{array}{c}\text { Unstandardized } \\
\text { Coefficients }\end{array}$} & $\begin{array}{c}\text { Standardized } \\
\text { Coefficients } \\
\text { Beta }\end{array}$ & $\mathrm{t}$ & Sig. \\
& \multicolumn{2}{|c|}{$\mathrm{B}$ Error } & Std. & & \\
\hline (Constant) & $-1,606$ & .327 & .545 & -4.905 & .000 \\
STATE & .668 & .225 & .965 & .005 \\
INDEPENDEN & -.374 & .318 & -.336 & -1.175 & .246 \\
POLCON & .394 & .177 & 1.162 & 2.232 &, 030 \\
SIZE & .037 & .011 & .528 & 3.311 & .002 \\
ROA & .890 & .296 & .400 & 3.004 & .004 \\
IO & -.072 & .047 & -.139 & -1.530 & .132 \\
CASH & .044 & .030 & .205 & 1.497 & .141 \\
DEBT & -.199 & .086 & -.341 & -2.321 & .024 \\
STATE_POLCON & -.807 & .239 & -1.585 & -3.382 & 0.001 \\
INDEPENDEN_POLCON & .284 & .324 & .425 & .876 & .385 \\
\hline
\end{tabular}

a. Dependent variabel: DPR

The equation regression for first regression model is as follows:

$D P R=-1,606+0,668$ STATE $-0,374$ INDEPENDEN + 0,037 SIZE + 0,890 ROA - 0,072 IO + 0,044 CASH

$-0,199$ DEBT $+0,394$ POLCON $-0,807$ STATE * POLCON + 0,284 INDEPENDEN * POLCON

It can be seen from table 1 that the significance of $t$ test for the STATE*POLCON is 0.001 , less than 0.05 or significant at level $1 \%$. It can be concluded that political connections moderating the effect of state ownership towards the dividend policy. These results indicate that the effect of state ownership on dividend policy is undermined by the existence of political connection variables. That is, when the political connection increases the influence of state ownership of dividend policy becomes weak. Thus, it can be said that hypothesis testing for $\mathrm{H} 3$ is accepted.

The $\mathrm{t}$ test for INDEPENDEN*POLCON is 0.385 or greater than 0.05 so it indicates that political connections do not have a moderating effect on the influence of the Independent Commissioner's variables toward the dividend policy. Thus, it can be said that hypothesis testing for $\mathrm{H} 4$ is declined.

\section{Conclusion And Recommendations}

Based on the analysis above, then the conclusions obtained from the study as follows:

State ownership of state-owned companies in Indonesia does not significantly affect the company's dividend policy. These results show that although the majority of state-owned shares are owned by the government but this does not affect the company's dividend payout ratio.

The composition of the Board of Independent Commissioners in the SOE companies has no effect on the company's dividend policy The number of Independent Commissioners has not been able to demonstrate effective oversight in accordance with the existing laws and regulations as there are still SOEs with the number of Independent Commissioners under 30\% of the total Board of Commissioners. 
The moderation variable of political connections proved to weaken the positive influence between state ownership on the dividend payout ratio. In other independent variables, the effect of the Independent Commissioner on the dividend payouts ratio is not proven to have a moderating effect by political connections. This means that state ownership of SOEs must be free from government intervention. and governments must work in accordance with their respective proportions. So that created a state-owned enterprises capable of competing in the domestic and global markets.

Firm size and profitability variables show a positive and significant influence on dividend policy, debt variable has negative and significant influence to dividend policy. While investment opportunity and liquidity control variables each have negative and positive influence but not significant to dividend policy variable.

\section{Recommendations}

For the policy makers, the government and the People's Legislative Assembly, to formulate regulations related to the obligation of state-owned dividend payouts to provide dividend policy standards both for companies and the government so that dividend policy does not burden SOEs in order to become a competitive company and able to compete in domestic and global level as well as in Malaysia and Singapore.

The importance of governance reform in state-owned enterprises in Indonesia, so that companies with the state ownership are not always in line with political interests in it but able to become a company that has a performance and reliable governance and can be trusted by all stakeholders, potential investors, as well as the market both domestic and global.

\section{References}

[1] Coase, R. H. (1937). The nature of the firm. economica, 4(16), 386-405. https://doi.org/10.1111/j.1468-0335.1937.tb00002.x

[2] Fama, E. F. (1980). Agency problems and the theory of the firm. Journal of political economy, 88(2), 288-307. https://doi.org/10.1086/260866

[3] Fan, J. P., Wong, T. J., \& Zhang, T. (2007). Politically connected CEOs, corporate governance, and Post-IPO performance of China's newly partially privatized firms. Journal of financial economics, 84(2), 330-357. https://doi.org/10.1016/j.jfineco.2006.03.008

[4] Friedman, E., Johnson, S., \& Mitton, T. (2003). Propping and tunneling. Journal of comparative economics, 31(4), 732-750. https://doi.org/10.1016/j.jce.2003.08.004

[5] Gang Wei, J., Zhang, W., \& ZeZhong Xiao, J. (2004). Dividend payment and ownership structure in China Corporate Governance (pp. 187-219): Emerald Group Publishing Limited.

[6] Habib, A., Muhammadi, A. H., \& Jiang, H. (2017). Political connections and related party transactions: Evidence from Indonesia. The International Journal of Accounting, 52(1), 45-63. https://doi.org/10.1016/j.intacc.2017.01.004

[7] Hermalin, B. E., \& Weisbach, M. S. (2003). Boards of directors as an endogenously.

[8] Jensen, M. C., \& Meckling, W. H. (1976). Theory of the firm: Managerial behavior, agency costs and ownership structure. Journal of financial economics, 3(4), 305-360. https://doi.org/10.1016/0304-405X(76)90026-X

[9] John, K., Knyazeva, A., \& Knyazeva, D. (2011). Does geography matter? Firm location and corporate payout policy. Journal of financial economics, 101(3), 533-551. https://doi.org/10.1016/j.jfineco.2011.03.014

[10] Kusuma, I. E. (2015). "Pengangkatan Direksi dan Komisaris BUMN "Balas Budi" Langgar Permen". Retrieved from $U R L$ http://www.aktual.com/pengangkatan-direksi-dan-komisaris-bumn-balas-budi-langgar-permen. diakses tanggal 25 Juni 2018 
[11] Li, S., Song, X., \& Wu, H. (2015). Political connection, ownership structure, and corporate philanthropy in China: A strategic-political perspective. Journal of Business Ethics, 129(2), 399-411. https://doi.org/10.1007/s10551-014-2167-y

[12] Sharma, V. (2011). Independent directors and the propensity to pay dividends. Journal of Corporate finance, 17(4), 1001-1015. https://doi.org/10.1016/j.jcorpfin.2011.05.003

[13] Shleifer, A., \& Vishny, R. W. (1994). Politicians and firms. The Quarterly Journal of Economics, 109(4), 995-1025. https://doi.org/10.2307/2118354

[14] Su, Z.-q., Fung, H.-G., Huang, D.-s., \& Shen, C.-H. (2014). Cash dividends, expropriation, and political connections: Evidence from China. International Review of Economics \& Finance, 29, 260-272. https://doi.org/10.1016/j.iref.2013.05.017

[15] Yu, M. (2013). State ownership and firm performance: Empirical evidence from Chinese listed companies. China Journal of Accounting Research, 6(2), 75-87.

https://doi.org/10.1016/j.cjar.2013.03.003 